Article

\title{
Inhibition of Biofilm Formation by Modified Oxylipins from the Shipworm Symbiont Teredinibacter turnerae
}

\author{
Noel M. Lacerna II ${ }^{1}$, Cydee Marie V. Ramones ${ }^{1}$, Jose Miguel D. Robes ${ }^{1}$, Myra Ruth D. Picart ${ }^{1}$, \\ Jortan O. Tun ${ }^{1}$, Bailey W. Miller ${ }^{2}{ }^{(1)}$, Margo G. Haygood ${ }^{2}$, Eric W. Schmidt ${ }^{2}$, \\ Lilibeth A. Salvador-Reyes ${ }^{1}$ (D) and Gisela P. Concepcion ${ }^{1, *}$ \\ 1 The Marine Science Institute, University of the Philippines Diliman, Quezon City 1101, Philippines; \\ noel.lacerna@utah.edu (N.M.I.II); cvramones@up.edu.ph (C.M.V.R.); miguel.robes@utah.edu (J.M.D.R.); \\ mdpicart@upd.edu.ph (M.R.D.P.); jortan.tun@utah.edu (J.O.T.); lsreyes@msi.upd.edu.ph (L.A.S.-R.) \\ 2 Department of Medicinal Chemistry, University of Utah, Salt Lake City, UT 84112, USA; \\ bailey.miller@utah.edu (B.W.M.); margo.haygood@utah.edu (M.G.H.); ews1@utah.edu (E.W.S.) \\ * Correspondence: gpconcepcion@up.edu.ph; Tel.: +632-8275-2877
}

Received: 23 November 2020; Accepted: 16 December 2020; Published: 20 December 2020

\begin{abstract}
The bioactivity-guided purification of the culture broth of the shipworm endosymbiont Teredinibacter turnerae strain 991H.S.0a.06 yielded a new fatty acid, turneroic acid (1), and two previously described oxylipins (2-3). Turneroic acid (1) is an 18-carbon fatty acid decorated by a hydroxy group and an epoxide ring. Compounds 1-3 inhibited bacterial biofilm formation in Staphylococcus epidermidis, while only 3 showed antimicrobial activity against planktonic S. epidermidis. Comparison of the bioactivity of 1-3 with structurally related compounds indicated the importance of the epoxide moiety for selective and potent biofilm inhibition.
\end{abstract}

Keywords: anti-biofilm; oxylipins; Staphylococcus epidermidis; Lyrodus; shipworm; Teredinibacter turnerae

\section{Introduction}

Microorganisms often colonize surfaces by creating a protected and nutritionally rich ecological niche called a biofilm [1]. Biofilms provide protected access to nutritional sources, facilitate cellular communication, and increase tolerance to antimicrobials in concentrations normally lethal to planktonic organisms [2,3]. Staphylococcus epidermidis, a normally commensal bacterium common in skin and mucous membranes that is pathogenic in certain circumstances, is considered the best-known example of a pathogen that uses biofilm formation as a virulence factor [4]. S. epidermidis biofilm-mediated infections represent the most common infections on indwelling medical devices, and the only effective treatment is the replacement of infected devices with new and uninfected ones [4,5]. Currently, research is focused on understanding the in-depth mechanism of biofilm formation. The use of small molecules affecting biofilm-associated infections could provide a solution to this longstanding problem.

Nature has historically been the most productive source of antibiotics [6]. In recent years, a strategy has been to search for bioactive compounds in previously overlooked habitats such as host-associated bacteria $[7,8]$. Shipworms (family: Teredinidae) are marine wood-boring bivalves that possess bacterial endosymbionts in bacteriocytes located in the gills $[9,10]$. The specialized intracellular bacteria support the host's nutrition by producing enzymes used to digest cellulose and fix nitrogen [11]. One of the major bacterial symbionts in shipworms is Teredinibacter turnerae, although several other species have also been identified. Genomic analysis of T. turnerae strain T7901 showed that an unusually high proportion of the genome (7\%) is devoted to secondary metabolism [12], comparable to that of the biomedically important Actinobacteria. The substantial investment of T. turnerae in secondary metabolite biosynthesis 
suggests a potential role for small molecules in the symbiotic relationship between T. turnerae and the shipworm host as well as other microorganisms. For example, the macrodiolide tartrolon antibiotics produced by T. turnerae T7901 were shown to inhibit other shipworm symbionts and free-living pathogenic bacteria [13]. The siderophore turnerbactins provide another mechanism for microbial competition in the host through iron sequestration [9]. However, despite the vast potential for natural product discovery highlighted by the genomic analysis, few compounds have been isolated and characterized from this interesting bacterial group.

In this study, we screened shipworm-associated microorganisms for antimicrobial and biofilm inhibitory activity. One of the bioactive isolates, Teredinibacter turnerae strain 991H.S.0a.06 from Lyrodus pedicellatus, was subjected to bioassay-guided fractionation, and gave the new compound turneroic acid (1), and two known fatty acids (2-3). Structure-activity comparison of 1-3 with related compounds provided insights into the critical pharmacophore for potent and selective biofilm inhibition.

\section{Results and Discussion}

\subsection{Structure Elucidation}

Turneroic acid (1) was purified as a white powder with $\lambda_{\max }$ of $230 \mathrm{~nm}$. HRESIMS of $\mathbf{1}$ showed a sodiated peak at $m / z 337.2363$, which was assigned to a molecular formula of $\mathrm{C}_{18} \mathrm{H}_{34} \mathrm{O}_{4} \mathrm{Na}$. The ${ }^{1} \mathrm{H}$ NMR profile of turneroic acid (1) showed characteristic signals for oxylipins with a terminal methyl $\left(\delta_{\mathrm{H}} 0.92\right)$, methylene envelope $\left(\delta_{\mathrm{H}} 1.33-1.35\right)$, and $\alpha$-methylenes $\left(\delta_{\mathrm{H}} 2.24\right)$ (Table 1 and Supplementary Figure S2). COSY, HSQC, and HMBC showed distinctive signals for a carboxylic acid $\left(\delta_{C} 178.1\right)$, an epoxide moiety $\left(\delta_{C} / \delta_{H} 63.4 / 2.67 ; 57.7 / 2.86\right)$, and a hydroxylated methine $\left(\delta_{C} / \delta_{H} 72.8 / 3.30\right)$. 2D NMR correlations allowed for the assignment of three partial structures (Figure 1). After the assignment of these partial structures a methylene envelope remained, consisting of a $\mathrm{C}_{5} \mathrm{H}_{10}$ unit in which the ${ }^{1} \mathrm{H}$ and ${ }^{13} \mathrm{C}$ shifts were overlapping. While minor impurities were observed in the TOCSY spectrum of 1 due to prolonged storage in solution, clear correlations were observed between H-13/H-18 and $\mathrm{H}-14 / \mathrm{H}-18$, and established the linkage between partial structures I and II. This was corroborated by the lack of TOCSY correlation between the terminal $\mathrm{CH}_{3}\left(\delta_{\mathrm{H}} 0.92\right)$ and the hydroxylated methine ( $\left.\delta_{\mathrm{H}} 3.30\right)$. HMBC correlations between H-2/C-4, H-9/C-8, H-9/C-7, and H-10/C-8 indicated that partial structures II and III were linked by the methylene envelope. Hence, the structure of $\mathbf{1}$ was assigned as 11-hydroxy-12,13-epoxy-octadecanoic acid. A somewhat similar compound, except with additional unsaturation, was previously synthesized, although no spectroscopic or configurational data were provided for the synthetic compound. Since the synthetic compound potentially consists of a mixture of four diastereomers as drawn, the identity of the compound is somewhat unclear [14]. A coupling constant of $2.1 \mathrm{~Hz}$ was observed for $\mathrm{H}-12$ and $\mathrm{H}-13$, indicating a trans configuration for the epoxide moiety (Table 1).

The ${ }^{1} \mathrm{H}$ NMR spectra of $\mathbf{2}$ and $\mathbf{3}$ also showed characteristic signals for fatty acids (Supplementary Materials Figures S11 and S12). The ${ }^{1} \mathrm{H}$ NMR and MS data for 2 matched the known compound (E)-9-oxohexadec-10-enoic acid, which was previously purified from the red alga Gracilaria verrucosa (Figure 2) [15]. The ${ }^{1} \mathrm{H}$ NMR data for 3 showed marked similarity with 2, indicating that these are analogues. HRESIMS analysis of 3 gave a 28 Da mass difference with 2, suggesting two additional methylenes in 3 . This is in accordance with the additional methylene protons observed in the ${ }^{1} \mathrm{H} N M R$ spectrum of 3 (Supplementary Materials Figure S12). Dereplication and further MS/MS fragmentation indicated that 3 was (E)-11-oxooctadec-12-enoic acid (Figure 2), previously reported from the marine green alga Ulva fasciata [16] (Supplementary Materials Figure S10). 
Table 1. NMR spectroscopic data for turneroic acid (1) in $\mathrm{CD}_{3} \mathrm{OD}$.

\begin{tabular}{cccccc}
\hline $\mathrm{C} / \mathrm{H}$ & $\delta \mathrm{C}^{a}$ & $\delta \mathbf{H}(\boldsymbol{J} \text { in } \mathbf{~ H z})^{b}$ & COSY $^{b}$ & TOCSY & HMBC $^{b}$ \\
\hline 1 & $178.1, \mathrm{C}$ & & & & \\
2 & $36.3, \mathrm{CH}_{2}$ & $2.24, \mathrm{t}(7.1)$ & 3 & 3,4 & $1,3,4$ \\
3 & $26.4, \mathrm{CH}_{2}$ & $1.60, \mathrm{~m}$ & 2,4 & 2,4 & $4 / 5$ \\
4 & $30.4, \mathrm{CH}_{2}$ & $1.33, \mathrm{~m}$ & $c$ & $c$ & 3 \\
5 & $30.4, \mathrm{CH}_{2}$ & $1.33, \mathrm{~m}$ & $c$ & $c$ & \\
6 & $30.4, \mathrm{CH}_{2}$ & $1.33, \mathrm{~m}$ & $c$ & $c$ & \\
7 & $30.4, \mathrm{CH}_{2}$ & $1.33, \mathrm{~m}$ & $c$ & $c$ & \\
8 & $30.4, \mathrm{CH}_{2}$ & $1.33, \mathrm{~m}$ & $c$ & $c$ & \\
9 & $26.5, \mathrm{CH}_{2}$ & $1.46, \mathrm{~m}$ & 8,10 & & $7 / 8,11$ \\
10 & $35.2, \mathrm{CH}_{2}$ & $1.53,1.34, \mathrm{~m}$ & 9,11 & 11 & 8,11 \\
11 & $72.8, \mathrm{CH}$ & $3.30, \mathrm{~m}$ & 10,12 & 10,12 & $9,10,12,13(\mathrm{w})$ \\
12 & $63.4, \mathrm{CH}$ & $2.67, \mathrm{dd}(6.6,2.1)$ & 11,13 & 11 & $11,13(\mathrm{w})$ \\
13 & $57.7, \mathrm{CH}$ & $2.86, \mathrm{td}(5.8,2.1)$ & 12,14 & $14,16,18$ & 14 \\
14 & $32.6, \mathrm{CH}_{2}$ & $1.54,1.35, \mathrm{~m}$ & 13,15 & $11,12,13,15$ & 12,13 \\
15 & $26.4, \mathrm{CH}_{2}$ & $1.35, \mathrm{~m}$ & $c$ & $c$ & \\
16 & $32.8, \mathrm{CH}_{2}$ & $1.45, \mathrm{~m}$ & 17 & 18 & \\
17 & $23.7, \mathrm{CH}_{2}$ & $1.35, \mathrm{~m}$ & 16,18 & 18 & 18 \\
18 & $14.3, \mathrm{CH}_{3}$ & $0.92, \mathrm{t}(7.1)$ & 17 & $13,14,15,16,17$ & 16,17 \\
\hline
\end{tabular}

${ }^{a} 125 \mathrm{MHz},{ }^{b} 500 \mathrm{MHz},{ }^{c}$ overlapping peaks.

Compounds 1 and 3 are structurally related. Both are 18-carbon fatty acids, with structural modifications at $\mathrm{C}-11-\mathrm{C}-13$. Turneroic acid (1) bears an epoxide at $\mathrm{C}-12-\mathrm{C}-13$ instead of a $\mathrm{C}=\mathrm{C}$ (as in 3), and a hydroxy instead of a keto group at C-11. This likely points to turneroic acid being a biotransformation product of 3 . This is analogous to the enzymatic and non-enzymatic conversion of linoleic acid to the corresponding hydroxyepoxy-octadecenoic acid in human plasma [14]. On the basis of 1 and $\mathbf{3}$ having the same biosynthetic origin, the relative configuration of the epoxide moiety in $\mathbf{1}$ is likely to be trans. This also corroborates with the assigned relative configuration of $\mathbf{1}$ based on the $J_{\mathrm{H} 12-\mathrm{H} 13}$. The ${ }^{1} \mathrm{H}$ NMR spectrum of 3 gave a coupling constant of $J \sim 15.7 \mathrm{~Hz}$ for the olefinic protons $\left(\delta_{\mathrm{H}}=6.12\right.$ and 6.95), suggesting a trans coupling between $\mathrm{H}-12$ and $\mathrm{H}-13$. The configuration of turneroic acid (1) could not be assigned due to insufficient material. Nonetheless, the structural features inspired us to explore biological activity using simpler analogues (see below).

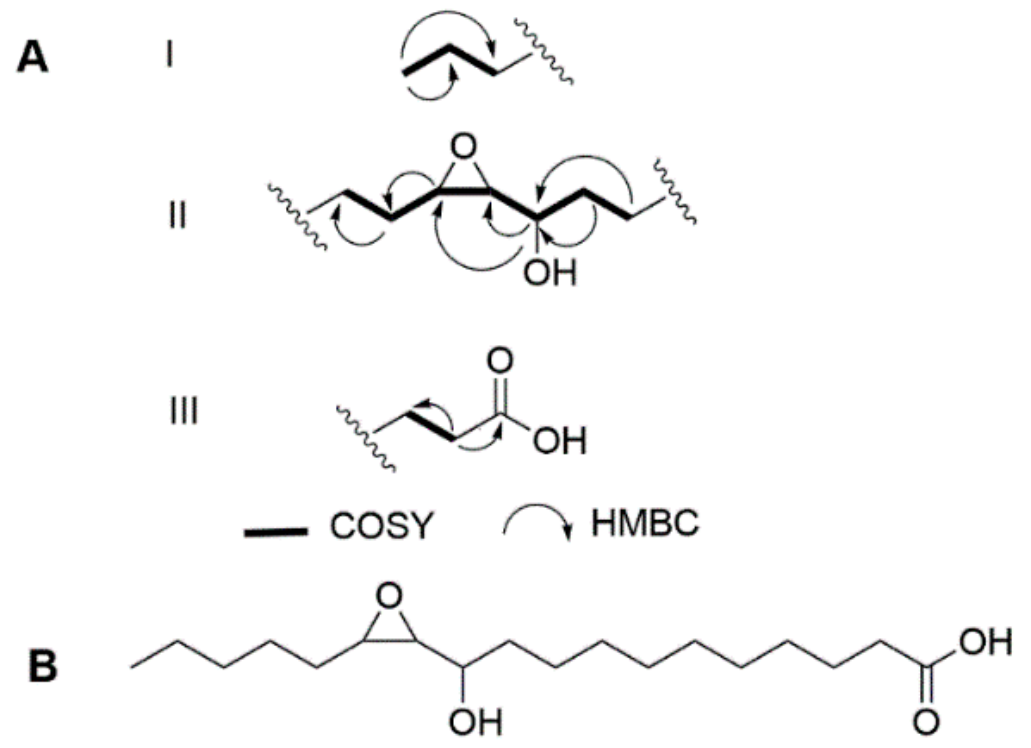

Figure 1. (A) Key fragments with COSY and HMBC correlations and (B) structure of turneroic acid (1). 


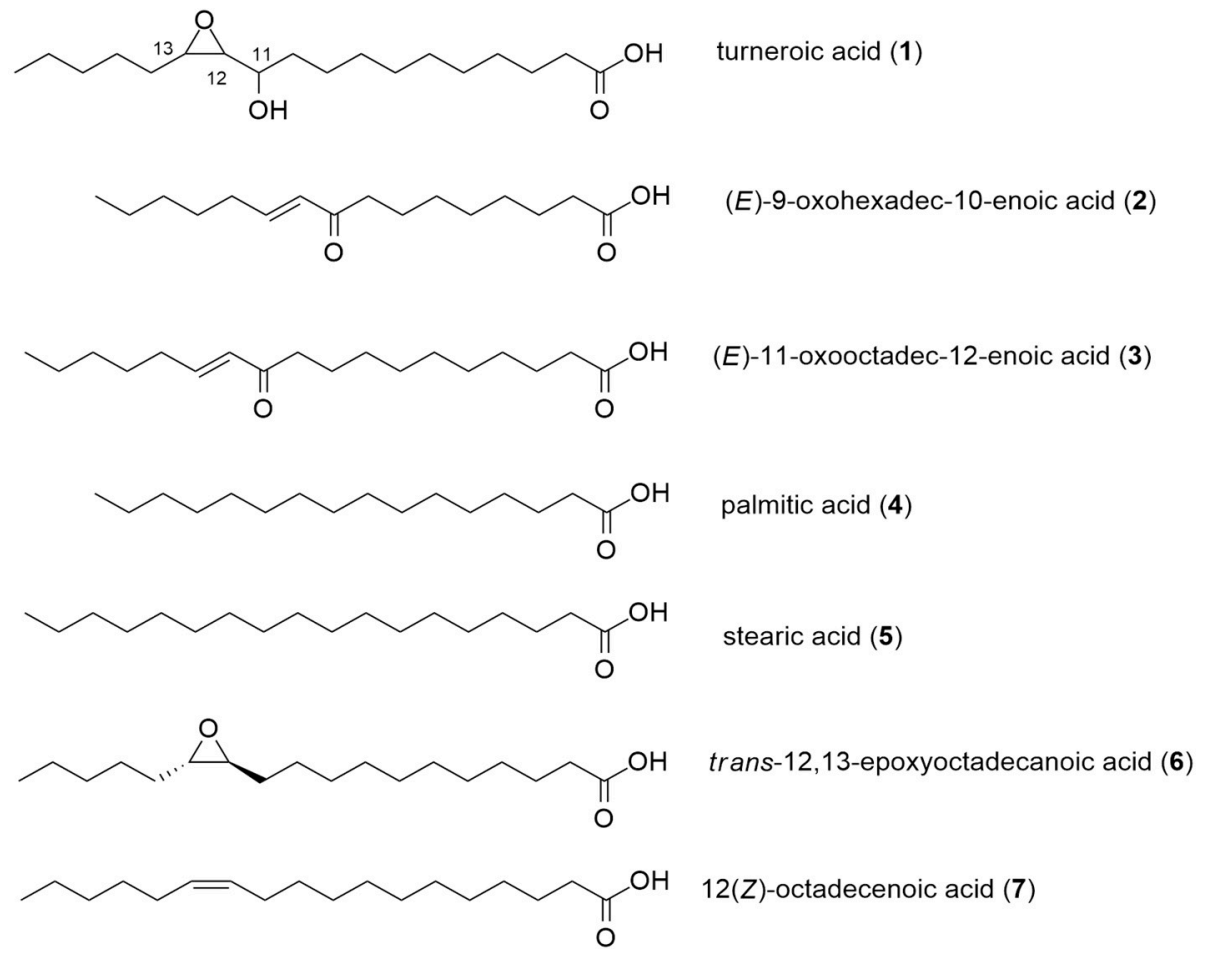

Figure 2. Structure of modified oxylipins.

\subsection{Biological Activities of Oxylipins (1-7)}

Compounds 1-3 are structurally related to the naturally occurring fatty acids palmitic acid (4) and stearic acid (5), as well as possible biotransformation compounds trans-12,13-epoxy-octadecanoic acid (6) and 12(Z)-octadecenoic acid (7) (Figure 2). All seven compounds were subjected to a panel of bioactivity assays to assess their effects on staphylococcal pathogens and mammalian cells (Table 2). Biofilm formation by S. epidermidis in the presence of 1-7 was determined by quantifying the biomass of the formed biofilm after $24 \mathrm{~h}$ of incubation using Alexa Fluor 488 (WGA488)-labelled wheat germ agglutinin. This fluorescent stain specifically binds to sialic acid and the $\mathrm{N}$-acetylglucosaminyl residues of the biofilm. The growth of planktonic Staphylococcus aureus, methicillin-resistant S. aureus, and S. epidermidis with 1-7 was monitored using the microdilution assay. Growth inhibition in the microbial pathogens was quantified by monitoring the conversion of resazurin to the fluorescent resorufin product. The cytotoxicity of 1-7 in mammalian cells was assessed at $72 \mathrm{~h}$ post-incubation using a tetrazolium-based assay.

Not surprisingly, saturated C16 and C18 fatty acids (palmitic (4) and stearic acids (5), respectively) did not show any significant bioactivity against microbial pathogens or mammalian cells (Table 2). Only 3 was bioactive against planktonic S. epidermidis (MIC $=16 \mu \mathrm{g} / \mathrm{mL}$ ), while 7 showed weak inhibition against planktonic S. aureus (MIC $=64 \mu \mathrm{g} / \mathrm{mL}$ ). Four of the seven compounds $(\mathbf{1}, \mathbf{2}, \mathbf{3}$, and $\mathbf{6})$ inhibited biofilm formation in S. epidermidis. Compound 3 demonstrated cytotoxicity in mammalian MDCK cells (Table 2).

A comparison of each structure to its bioactivity profile shows that decoration of the hydrophobic chain with various functional groups led to a variety of biological activities. For example, in the C16 fatty acids 2 and 4 , the addition of an $\alpha, \beta$-unsaturation in 4 led to cytotoxic activity against mammalian cells and modest inhibition of biofilm formation in S. epidermidis (Table 2). Comparing 2 and 3 , the addition of one $\mathrm{CH}_{2}$ group in the latter resulted in potent but non-selective activity against biofilm, planktonic S. epidermidis, and MDCK cells. Improved selectivity for biofilm inhibition was observed for compounds bearing an epoxide ring, as in $\mathbf{1}$ and $\mathbf{6}$. The selectivity index increased by 
two- to four-fold with the introduction of the epoxide functionality. At the same time, 6 showed no antiproliferative action in mammalian cells.

Table 2. Minimum inhibitory concentration (MIC) and minimum biofilm inhibition concentration (MBIC) of 1-7 against staphyloccocal pathogens ${ }^{a}$.

\begin{tabular}{|c|c|c|c|c|c|c|}
\hline Compounds & $\begin{array}{c}\text { MBIC }(\mu \mathrm{g} / \mathrm{mL}) \\
\text { S. epidermidis } \\
\text { RP62A } \\
\text { (ATCC }^{\circledR} 35984^{\mathrm{TM}} \text { ) }\end{array}$ & $\begin{array}{c}\mathrm{MIC}(\mu \mathrm{g} / \mathrm{mL}) \\
\text { S. epidermidis } \\
\text { RP62A } \\
\text { (ATCC }^{\circledR} 35984^{\mathrm{TM}} \text { ) }\end{array}$ & $\begin{array}{c}\text { Selectivity } \\
\text { Index } \\
\text { (MIC }_{\text {Planktonic }} \\
\text { /MBIC } \text { Biofilm }^{\text {(Ming }}\end{array}$ & $\begin{array}{c}\mathrm{MIC}(\mu \mathrm{g} / \mathrm{mL}) \\
\text { S. aureus } \\
\text { (ATCC }^{\circledR} 6538^{\mathrm{TM}} \text { ) }\end{array}$ & $\begin{array}{c}\text { MIC }(\mu \mathrm{g} / \mathrm{mL}) \\
\text { Methicillin- } \\
\text { Resistant } \\
\text { S. aureus } \\
\text { (ATCC }{ }^{\circledR} 43,300^{\mathrm{TM}} \text { ) }\end{array}$ & $\begin{array}{c}\mathrm{IC}_{50}(\mu \mathrm{g} / \mathrm{mL}) \\
\mathrm{MDCK} \mathrm{NBL}-2 \\
\left(\text { (ATCC }^{\circledR} \text { CCL-34 }\right.\end{array}$ \\
\hline 1 & 32 & 128 & $\sim 4$ & $>128$ & $>128$ & 61.7 \\
\hline 2 & $>128$ & $>128$ & $\sim 1$ & $>128$ & $>128$ & 33.0 \\
\hline 3 & 16 & 16 & $\sim 1$ & $>128$ & $>128$ & 13.6 \\
\hline 6 & 16 & $>128$ & $>8$ & $>128$ & $>128$ & $>128$ \\
\hline 7 & $>128$ & $>128$ & $\sim 1$ & 64.0 & $>128$ & $>128$ \\
\hline dispersin B & 64 & $>>128$ & $>>2$ & $\mathrm{n} / \mathrm{a}$ & $\mathrm{n} / \mathrm{a}$ & $\mathrm{n} / \mathrm{a}$ \\
\hline chloramphenicol & $\mathrm{n} / \mathrm{a}$ & 8.0 & $\mathrm{n} / \mathrm{a}$ & $\mathrm{n} / \mathrm{a}$ & $\mathrm{n} / \mathrm{a}$ & $\mathrm{n} / \mathrm{a}$ \\
\hline oxacillin & $\mathrm{n} / \mathrm{a}$ & $\mathrm{n} / \mathrm{a}$ & $\mathrm{n} / \mathrm{a}$ & 0.5 & 8 & $\mathrm{n} / \mathrm{a}$ \\
\hline
\end{tabular}

${ }^{a}$ Data presented as MIC of two independent trials performed in quadruplicates. MIC defined as the lowest concentration with $>98 \%$ growth inhibition. MBIC defined as the lowest concentration causing a $>98 \%$ inhibition of biofilm formation. $\mathrm{n} / \mathrm{a}=$ not applicable.

The potency and selectivity of the oxylipins are dictated by the addition of functional groups to the lipophilic chain. Having an electrophilic center improves the potency, while the nature of the functional groups tunes the selectivity. Electrophilic centers are a common feature among other compounds with biofilm-inhibitory activity such as in cis-2-decenoic acid [17,18], cinnamaldehyde [19], pentadecanal [20], 5-dodecanolide [21], parthenolide [22], and cembranoid alkaloid [23]. Pentadecanal, from the marine bacterium Pseudoalteromonas haloplanktis TAC125, is structurally related to the Vibrio harveyi quorum-sensing molecule tetradecanal [20]. Biofilm formation in methicillin-resistant S. aureus (MRSA) is restricted by 5-dodecanolide, which decreases the expression of the quorum-sensing genes $\operatorname{agr} A$ and $\operatorname{agrC}$, consequently downregulating the expression of effector genes involved in biofilm formation [21]. The transcriptional effect of 5-dodecanolide is suggested to affect the early stages of biofilm formation by modulating the levels of adhesion proteins [21]. The anti-biofilm compounds 1-3 and 6 are similar to reactive electrophilic oxylipins which possess the qualities of being lipophilic and thiol-reactive. Thiol modification is assumed to represent a key mechanism in signal transduction [24]. These oxylipins chemically modify several proteins-particularly thioredoxins, which function in redox signaling and oxidative stress responses. A thioredoxin $\operatorname{tr} x \mathrm{H}_{E p}$, from the fish pathogen Edwardsiella piscicida was identified as contributing to the microorganism's adversity adaptation and its pathogenicity [25]. The deletion of $t r x H_{E p}$ led to retarded bacterial biofilm growth [25]. Because the anti-biofilm activity is correlated with the presence of thiol-reactive groups, it is possible that 1-3 and 6 function similarly by covalently modifying bacterial proteins. Further work is required to test this hypothesis.

The existence of anti-biofilm compounds such as 1-3 from T. turnerae may have an ecological relevance to the shipworm host. Compounds 1-3 could be part of an arsenal of compounds, including the previously reported tartrolons and turnerbactin, for suppressing microbial growth within the caecum of the shipworm host, where lignocellulose is degraded and glucose is liberated. This would constitute a complex strategy involving the inhibition of biofilms with 1-3, sequestration of iron by turnerbactin, and planktonic cell-killing by tartrolons in order to limit the proliferation of competing microbes $[9,13]$. Furthermore, the biotransformation of fatty acids to oxylipins by T. turnerae highlights an effective strategy to modulate the potency and selectivity of biological activity, starting with simple and abundant fatty acid precursors. 


\section{Materials and Methods}

\subsection{General Experimental Procedures}

${ }^{1} \mathrm{H},{ }^{13} \mathrm{C}$, and 2D NMR data were collected using a Varian Inova $500 \mathrm{MHz}$ spectrometer equipped with a $3 \mathrm{~mm}$ NMR probe using residual solvent signals for referencing. Low-resolution ESIMS was done using a Shimadzu 8040 through direct injection in 50\% MeOH: $\mathrm{H}_{2} \mathrm{O}$ with 0.1\% formic acid. High-resolution MS (HRMS) data were obtained using Waters Xevo G2 XS QTOF through direct infusion using $50 \%$ aqueous ACN with $0.1 \%$ formic acid. HPLC purification was done using a Shimadzu High-Performance Liquid Chromatograph (HPLC) equipped with binary pumps, fraction collector, and photodiode array detector (Shimadzu Kyoto, Japan). Fatty acids palmitic (4) and stearic acids (5) were sourced from Sigma-Aldrich (St. Louis, MO, USA). ( \pm ) trans-12,13-epoxy-octadecanoic acid (6) and 12(Z)-octadecenoic acid (7) were purchased from Larodan Fine Chemicals (Solna, Sweden).

\subsection{Biological Material}

T. turnerae strain 991H.S.0a.06 was obtained from the gill of Lyrodus pedicellatus collected in Panglao, Bohol, and identified through the amplification and sequencing of $16 \mathrm{~S}$ rRNA genes using primers 27F (5'-AGAGTTTGATCMTGGCTCAG-3') and 1492R (5'-TACGGYTACCTTGTTACGACTT-3'). Sequences were submitted to GenBank with accession number MH379668.

\subsection{Culturing and Extraction}

T. turnerae 991H.S.0a.06 was grown for 7 days using a Shipworm Basal Medium broth (SBM) at $30{ }^{\circ} \mathrm{C}, 250 \mathrm{rpm}$. The SBM contained sucrose $(5 \mathrm{~g} / \mathrm{L}), \mathrm{NaCl}(19.8 \mathrm{~g} / \mathrm{L}), \mathrm{NH}_{4} \mathrm{Cl}(267.5 \mathrm{mg} / \mathrm{L})$, $\mathrm{MgCl}_{2} \cdot 6 \mathrm{H}_{2} \mathrm{O}(8.95 \mathrm{~g} / \mathrm{L}), \mathrm{Na}_{2} \mathrm{SO}_{4}(3.31 \mathrm{~g} / \mathrm{L}), \mathrm{CaCl}_{2} \cdot 2 \mathrm{H}_{2} \mathrm{O}(1.25 \mathrm{~g} / \mathrm{L}), \mathrm{NaHCO}_{3}(0.162 \mathrm{~g} / \mathrm{L}), \mathrm{Na}_{2} \mathrm{CO}_{3}$ (10 mg/L), $\mathrm{KCl}(0.552 \mathrm{mg} / \mathrm{L}), \mathrm{KBr}(81 \mathrm{mg} / \mathrm{L}), \mathrm{H}_{3} \mathrm{BO}_{3}(21.5 \mathrm{mg} / \mathrm{L}), \mathrm{SrCl}_{2} \cdot 6 \mathrm{H}_{2} \mathrm{O}(19.8 \mathrm{mg} / \mathrm{L}), \mathrm{KH}_{2} \mathrm{PO}_{4}$ (3.82 mg/L), NaF (2.48 mg/L), $\mathrm{Na}_{2} \mathrm{MoO}_{4} \cdot 2 \mathrm{H}_{2} \mathrm{O}(2.5 \mathrm{mg} / \mathrm{L}), \mathrm{MnCl}_{2} \cdot 4 \mathrm{H}_{2} \mathrm{O}(1.8 \mathrm{mg} / \mathrm{L}), \mathrm{ZnSO}_{4} .7 \mathrm{H}_{2} \mathrm{O}$ $(0.22 \mathrm{mg} / \mathrm{L}), \mathrm{CuSO}_{4} \cdot 5 \mathrm{H}_{2} \mathrm{O}(0.079 \mathrm{mg} / \mathrm{L}), \mathrm{Co}\left(\mathrm{NO}_{3}\right)_{2} \cdot 6 \mathrm{H}_{2} \mathrm{O}(0.049 \mathrm{mg} / \mathrm{L}), \mathrm{Fe}-\mathrm{EDTA}$ complex $(4.15 \mathrm{mg} / \mathrm{L})$, and HEPES $(4.76 \mathrm{~g} / \mathrm{L})$ adjusted to $\mathrm{pH}=8.0$. After the incubation period the broth was centrifuged, and the supernatant was extracted with $\mathrm{HP} 20^{\mathrm{TM}}$ Diaion resin for $2 \mathrm{~h}$. The filtered resin was washed with $\mathrm{H}_{2} \mathrm{O}, 75 \%$ aqueous $\mathrm{MeOH}$, and then eluted with $100 \% \mathrm{MeOH}$. The methanolic extract was dried under reduced pressure to yield the crude extract. This was subjected to solvent partitioning $(3 \times)$ with EtOAc: $\mathrm{H}_{2} \mathrm{O}(1: 1 \mathrm{v} / \mathrm{v})$. The bioactive organic extract was separated into four fractions using reversed phase $\mathrm{C} 18$ column chromatography with a step-gradient elution of $\mathrm{MeOH}$ in $\mathrm{H}_{2} \mathrm{O}(40 \%$, $60 \%, 80 \%$, and $100 \%$ ). The bioactive $100 \% \mathrm{MeOH} \mathrm{C18}$ open-column fraction was further separated by size exclusion chromatography (Sephadex LH20) using MeOH as the eluting solvent. A total of 16 LH20 fractions were collected and subjected to silica thin-layer chromatography (TLC) using a 9:1 $\mathrm{CH}_{2} \mathrm{Cl}_{2}$ :MeOH system as the developing solvent. Fractions were pooled based on similarity of the TLC profile to generate four fractions (Fractions 1-4). LH20 Fraction 2 was subjected using semipreparative reversed phase HPLC (Varian Polaris C-18 A-50, $250 \times 10 \mathrm{~mm}, 5 \mu \mathrm{m}$; flowrate: $3.00 \mathrm{~mL} / \mathrm{min}$ ) in a linear gradient of $\mathrm{MeOH}: \mathrm{H}_{2} \mathrm{O}$ with $0.1 \%$ TFA as solvent system $\left(60 \% \mathrm{MeOH}: \mathrm{H}_{2} \mathrm{O}\right.$ for $5 \mathrm{~min}, 60-100 \%$ MeOH: $\mathrm{H}_{2} \mathrm{O}$ over $7.5 \mathrm{~min}, 100 \% \mathrm{MeOH}$ for $5 \mathrm{~min}$ ). Fractions were collected at 1 min intervals using a fraction collector. The bioactive fraction with $t_{R}=15.0 \mathrm{~min}$, exhibiting antibiofilm activity, was further purified by semipreparative HPLC (Phenomenex Luna C18, $5 \mu \mathrm{m} ; 250 \times 10 \mathrm{~mm}$; flow rate, $3 \mathrm{~mL} / \mathrm{min}$ ) using a linear gradient of $\mathrm{MeOH}: \mathrm{H}_{2} \mathrm{O}$ with 0.1\% TFA (75\% MeOH: $\mathrm{H}_{2} \mathrm{O}$ for 5 min, 75-95\% MeOH:H $\mathrm{H}_{2} \mathrm{O}$ over $5 \mathrm{~min}, 100 \% \mathrm{MeOH}$ for $15 \mathrm{~min})$ to afford turneroic acid $\left(\mathbf{1}, \mathrm{t}_{\mathrm{R}}=14.7 \mathrm{~min}, 1.4 \mathrm{mg}\right)$. LH20 Fraction 4 was also fractionated using semipreparative RP-HPLC (Varian Polaris C-18 A-50, $250 \times 10 \mathrm{~mm}, 5 \mu \mathrm{m}$; flowrate: $3 \mathrm{~mL} / \mathrm{min}$ ) with $\mathrm{MeOH}: \mathrm{H}_{2} \mathrm{O}$ with $0.1 \%$ TFA as solvent system (75-100\% $\mathrm{MeOH}: \mathrm{H}_{2} \mathrm{O}$ in $25 \mathrm{~min}, 100 \% \mathrm{MeOH}$ for $5 \mathrm{~min})$ to afford $2\left(3.2 \mathrm{mg}, \mathrm{t}_{\mathrm{R}}=13.5 \mathrm{~min}\right)$ and $3\left(6.5 \mathrm{mg}, \mathrm{t}_{\mathrm{R}}=17.4 \mathrm{~min}\right)$.

Turneroic acid/11-hydroxy-12,13-epoxyoctadecanoic acid (1): white powder; UV (MeOH $+0.1 \%$ TFA) $\lambda_{\max } 230 \mathrm{~nm}$; LC-ESIMS m/z 315.40 [M + H] ${ }^{+}$; HRESIMS m/z 337.2363 [M + Na] ${ }^{+}$(calcd. for $\left.\mathrm{C}_{18} \mathrm{H}_{34} \mathrm{O}_{4} \mathrm{Na} 337.2355\right) ;{ }^{1} \mathrm{H}$ NMR and ${ }^{13} \mathrm{C}$ NMR data, see Table 1. 


\subsection{Antimicrobial Microdilution Assay}

The effects of 1-7 on planktonic S. aureus and methicillin-resistant S. aureus were assessed using a rezasurin-based method, as described in Lacerna et al. (2019) [26] and based on Sarker et al. (2007) [27]. In brief, Staphylococcus aureus (ATCC6538) and methicillin-resistant S. aureus (MRSA) (ATCC43300) were grown in Mueller Hinton broth (MHB) and treated with 1-7 after $24 \mathrm{~h}$ of inoculation. Compounds were tested using a two-fold dilution scheme from $0.25-128 \mu \mathrm{g} / \mathrm{mL}$. After $24 \mathrm{~h}$ of incubation, $0.02 \%$ resazurin $(20 \mu \mathrm{L})$ was added to each well, and the fluorescence was measured at $530 \mathrm{~nm}$ excitation and $590 \mathrm{~nm}$ emission. MIC is the lowest concentration at which there was no reduction of the rezasurin dye, equivalent to $98 \%$ inhibition of microbial growth. Assays were done in two independent trials with four independent replicates.

\subsection{Biofilm Inhibition Assay}

The biofilm inhibition assay was done according to the method of Skogman et al. (2012) [28]. A glycerol stock of Staphylococcus epidermidis RP62A (ATCC35984) was revived on Congo red agar (CRA) plates and phenotypically characterized to form rough black colonies, suggesting its ability to produce the biofilm. A single colony from the CRA plate was transferred in $50 \mathrm{~mL}$ trypticasein soy broth supplemented with glucose (TSBg) and grown overnight at $35^{\circ} \mathrm{C}, 150 \mathrm{rpm}$. The turbidity of the culture was adjusted to match the $0.5 \mathrm{McFarland}$ standard $\left(1 \times 10^{8}\right.$ cells $\left./ \mathrm{mL}\right)$ and diluted 100 -fold prior to inoculation in a 96-well plate. These were treated with compounds 1, 4-7, in a series of two-fold dilution starting at $128 \mu \mathrm{g} / \mathrm{mL}$ to $0.250 \mu \mathrm{g} / \mathrm{mL}$. Compounds $\mathbf{2}-\mathbf{3}$ were tested using half-log dilutions starting at $500 \mu \mathrm{g} / \mathrm{mL}$. TSBg served as the negative control, and positive controls were chloramphenicol (Sigma-Aldrich) for planktonic cells and dispersin B (Kane Biotech) for biofilms. Dispersin B is a $40 \mathrm{kDa}$ glycoside hydrolase which dissolves mature bacterial biofilms [29]. The plates were incubated for $20 \mathrm{~h}$ at $37^{\circ} \mathrm{C}$ without shaking to facilitate biofilm formation. At the end of the incubation period, the planktonic suspension was transferred to another 96-well plate to assess cell viability. A $20 \mu \mathrm{L}$-aliquot of $0.02 \%$ resazurin was added to each well and incubated for $30 \mathrm{~min}$ at $37^{\circ} \mathrm{C}$, $150 \mathrm{rpm}$. Fluorescence was measured using a $530 \mathrm{~nm}$ excitation filter and a $590 \mathrm{~nm}$ emission filter. To quantify the formed biofilm, $100 \mu \mathrm{L}$-aliquot of wheat germ agglutinin Alexa Fluor 488 (WGA488) probe $(50 \mu \mathrm{g} / \mathrm{mL})$ was added to each well of the original plate and incubated in the dark at $4{ }^{\circ} \mathrm{C}$ for $5 \mathrm{~h}$. At the end of incubation, the plate was washed with sterile PBS $(3 \times)$ and air-dried at room temperature to remove the unbound WGA488 probe. Bound stain to the biofilm was dissolved in $33 \%$ glacial acetic acid and quantified by fluorescence measurement at $485 \mathrm{~nm} / 420 \mathrm{~nm}$ excitation filters, and $528 \mathrm{~nm} / 520 \mathrm{~nm}$ emission filters. Minimum biofilm inhibitory concentration (MBIC) is the lowest concentration that resulted in $98 \%$ inhibition of biofilm formation. This was done in two independent trials with four independent replicates.

\subsection{Mammalian Antiproliferative Assay}

The mammalian antiproliferative assay was done according to Lacerna et al. (2019) and modified from the method of Mossman (1983) [30]. MDCK NBL-2 (ATCC CCL-34) cells were treated with 1-7 at half-log dilution starting at $500 \mu \mathrm{g} / \mathrm{mL}$. At $72 \mathrm{~h}$ post-incubation, the cells were treated with MTT and the absorbance at $570 \mathrm{~nm}$ was read. The $\mathrm{IC}_{50}$ was calculated using GraphPad Prism 5 based on a 4-point sigmoidal non-linear regression analysis of cell viability vs. log concentration of the inhibitor. The assay was done in two independent trials with four independent replicates.

Supplementary Materials: The following are available online at http://www.mdpi.com/1660-3397/18/12/656/s1. Figures S1-S6: HRMS, ${ }^{1} \mathrm{H}$ NMR, COSY, HSQC, HMBC, and TOCSY spectra of turneroic acid (1); Figures S7 and S8: LC-ESI-MS of 2 and 3; Figures S9 and S10: MS/MS spectra of 2 and 3; Figures S11 and S12: ${ }^{1} \mathrm{H}$ NMR spectra of 2 and 3; Figures S13-S15: Concentration-dependent curves of 1-7 against S. epidermidis biofilm formation and planktonic S. epidermidis cells; Figure S16: Concentration-dependent curve of oxacillin against S. aureus and methicillin-resistant $S$. aureus. 
Author Contributions: Conceptualization, N.M.I.II, J.M.R., L.A.S.-R., and G.P.C.; methodology, N.M.I.II, C.V.R., J.M.R., M.R.D.P., J.O.T., and L.A.S.-R.; writing—original draft preparation, N.M.I.II, L.A.S.-R., and G.P.C.; review and editing- N.M.I.II, B.W.M., M.G.H., E.W.S., L.A.S.-R., and G.P.C.; funding acquisition, M.G.H. and G.P.C. All authors have read and agreed to the published version of the manuscript.

Funding: Research reported in this publication was supported by the Fogarty International Center of the National Institutes of Health under Award Number U19TW008163. The content is solely the responsibility of the authors and does not necessarily represent the official views of the National Institutes of Health. The work was completed under supervision of the Department of Agriculture-Bureau of Fisheries and Aquatic Resources, Philippines (DA-BFAR) in compliance with all required legal instruments and regulatory issuances covering the conduct of the research. This work is part of the MSc and BSc thesis of N. Lacerna and C. Ramones, respectively.

Conflicts of Interest: The authors declare no conflict of interest.

\section{References}

1. Donlan, R.M. Role of Biofilms in Antimicrobial Resistance. ASAIO J. 2000, 46, S47-S52. [CrossRef] [PubMed]

2. Roy, R.; Tiwari, M.; Donelli, G.; Tiwari, V. Strategies for combating bacterial biofilms: A focus on anti-biofilm agents and their mechanisms of action. Virulence 2018, 9, 522-554. [CrossRef] [PubMed]

3. Santos, A.L.S.D.; Galdino, A.C.M.; De Mello, T.P.; Ramos, L.D.S.; Branquinha, M.H.; Bolognese, A.M.; Neto, J.C.; Roudbary, M. What are the advantages of living in a community? A microbial biofilm perspective! Memórias do Instituto Oswaldo Cruz 2018, 113, e180212. [CrossRef] [PubMed]

4. Otto, M. Staphylococcal Biofilms. Curr. Top. Microbiol. Immunol. 2008, 322, 207-228.

5. Otto, M. Staphylococcus epidermidis-The "accidental" pathogen. Nat. Rev. Microbiol. 2009, 7, 555-567. [CrossRef]

6. Rossiter, S.E.; Fletcher, M.H.; Wuest, W.M. Natural products as platforms to overcome antibiotic resistance. Chem. Rev. 2017, 117, 12415-12474. [CrossRef]

7. Schmidt, E.W. Trading molecules and tracking targets in symbiotic interactions. Nat. Chem. Biol. 2008, 4, 466-473. [CrossRef]

8. Piel, J. Metabolites from symbiotic bacteria. Nat. Prod. Rep. 2009, 26, 338-362. [CrossRef]

9. Han, A.W.; Sandy, M.; Fishman, B.; Trindade-Silva, A.E.; Soares, C.A.G.; Distel, D.L.; Butler, A.; Haygood, M.G. Turnerbactin, a Novel Triscatecholate Siderophore from the Shipworm Endosymbiont Teredinibacter turnerae T7901. PLoS ONE 2013, 8, e76151. [CrossRef]

10. Distel, D.L.; Altamia, M.A.; Lin, Z.; Shipway, J.R.; Han, A.; Forteza, I.; Antemano, R.; Limbaco, M.G.J.P.; Tebo, A.G.; Dechavez, R.; et al. Discovery of chemoautotrophic symbiosis in the giant shipwormKuphus polythalamia(Bivalvia: Teredinidae) extends wooden-steps theory. Proc. Natl. Acad. Sci. USA 2017, 114, E3652-E3658. [CrossRef]

11. Waterbury, J.B.; Calloway, C.B.; Turner, R.D. A Cellulolytic Nitrogen-Fixing Bacterium Cultured from the Gland of Deshayes in Shipworms (Bivalvia: Teredinidae). Science 1983, 221, 1401-1403. [CrossRef] [PubMed]

12. Yang, J.C.; Madupu, R.; Durkin, A.S.; Ekborg, N.A.; Pedamallu, C.S.; Hostetler, J.B.; Radune, D.; Toms, B.S.; Henrissat, B.; Coutinho, P.M.; et al. The Complete Genome of Teredinibacter turnerae T7901: An Intracellular Endosymbiont of Marine Wood-Boring Bivalves (Shipworms). PLoS ONE 2009, 4, e6085. [CrossRef] [PubMed]

13. Elshahawi, S.I.; Trindade-Silva, A.E.; Hanora, A.; Han, A.W.; Flores, M.S.; Vizzoni, V.; Schrago, C.G.; Soares, C.A.G.; Concepcion, G.P.; Distel, D.L.; et al. Boronated tartrolon antibiotic produced by symbiotic cellulose-degrading bacteria in shipworm gills. Proc. Natl. Acad. Sci. USA 2013, 110, E295-E304. [CrossRef] [PubMed]

14. Yuan, Z.-X.; Majchrzak-Hong, S.; Keyes, G.S.; Iadarola, M.J.; Mannes, A.J.; Ramsden, C.E. Lipidomic profiling of targeted oxylipins with ultra-performance liquid chromatography-tandem mass spectrometry. Anal. Bioanal. Chem. 2018, 410, 6009-6029. [CrossRef]

15. Hung, T.D.; Hye, J.L.; Eun, S.Y.; Shinde, P.B.; Yoon, M.L.; Hong, J.; Kim, D.K.; Jung, J.H. Anti-inflammatory constituents of the Red Alga Gracilaria verrucosa and their synthetic analogues. J. Nat. Prod. 2008, 71, 232-240.

16. Abou-ElWafa, G.S.E.; Shaaban, M.; Shaaban, K.A.; El-Naggar, M.E.E.; Laatsch, H. Three New Unsaturated Fatty Acids from the Marine Green Alga Ulva fasciata Delile. Zeitschrift für Naturforschung B 2009, 64, 1199-1207. [CrossRef] 
17. Davies, D.; Marques, C. A fatty acid messenger is responsible for inducing dispersion in microbial biofilms. J. Bacteriol. 2009, 191, 1393-1403. [CrossRef]

18. Marques, C.; Morozoz, A.; Planzos, P.; Zelaya, H. The fatty acid signaling molecule cis-2-decenoic acid increases metabolic activity and reverts persister cells to an antimicrobial-susceptible state. Appl. Environ. Microbiol. 2014, 80, 6976-6991. [CrossRef]

19. Topa, S.H.; Subramoni, S.; Palombo, E.A.; Kingshott, P.; Rice, S.A.; Blackall, L.L. Cinnamaldehyde disrupts biofilm formation and swarming motility of Pseudomonas aeruginosa. Microbiology 2018, 164, 1087-1097. [CrossRef]

20. Casillo, A.; Papa, R.; Ricciardelli, A.; Sannino, F.; Ziaco, M.; Tilotta, M.; Selan, L.; Marino, G.; Corsaro, M.M.; Tutino, M.L.; et al. Anti-Biofilm Activity of a Long-Chain Fatty Aldehyde from Antarctic Pseudoalteromonas haloplanktis TAC125 against Staphylococcus epidermidis Biofilm. Front. Cell. Infect. Microbiol. 2017, 7, 46. [CrossRef]

21. Valliammai, A.; Sethupathy, S.; Priya, A.; Selvaraj, A.; Bhaskar, J.P.; Krishnan, V.; Pandian, S.K. 5-Dodecanolide interferes with biofilm formation and reduces the virulence of Methicillin-resistant Staphylococcus aureus (MRSA) through up regulation of agr system. Sci. Rep. 2019, 9, 1-16. [CrossRef] [PubMed]

22. Romero, D.; Sanabria-Valentín, E.; Vlamakis, H.; Kolter, R. Biofilm Inhibitors that Target Amyloid Proteins. Chem. Biol. 2013, 20, 102-110. [CrossRef] [PubMed]

23. Camacho, E.T.; Castellanos, L.; Arévalo-Ferro, C.; Duque, C. Disruption in Quorum-Sensing Systems and Bacterial Biofilm Inhibition by Cembranoid Diterpenes Isolated from the Octocoral Eunicea knighti. J. Nat. Prod. 2012, 75, 1637-1642. [CrossRef]

24. Mueller, M.J.; Berger, S. Reactive electrophilic oxylipins: Pattern recognition and signalling. Phytochem. 2009, 70, 1511-1521. [CrossRef]

25. Wang, B.-Y.; Huang, H.-Q.; Li, S.; Tang, P.; Dai, H.; Xian, J.-A.; Sun, D.-M.; Hu, Y. Thioredoxin H (TrxH) contributes to adversity adaptation and pathogenicity of Edwardsiella piscicida. Veter- Res. 2019, 50, 26. [CrossRef] [PubMed]

26. Lacerna, I.N.M.; Miller, B.W.; Lim, A.L.; Tun, J.O.; Robes, J.M.D.; Cleofas, M.J.B.; Lin, Z.; Salvador-Reyes, L.A.; Haygood, M.G.; Schmidt, E.W.; et al. Mindapyrroles A-C, Pyoluteorin Analogues from a Shipworm-Associated Bacterium. J. Nat. Prod. 2019, 82, 1024-1028. [CrossRef]

27. Sarker, S.D.; Nahar, L.; Kumarasamy, Y. Microtitre plate based antibacterial assay incorporatin resazurin as an indicator of cell growth, and its applications in the in vitro antibacterial screening of phytochemicals. Methods 2007, 42, 321-324. [CrossRef]

28. Skogman, M.E.; Vuorela, P.M.; Fallarero, A. Combining biofilm matrix measurements with biomass and viability assays in susceptibility assessments of antimicrobials against Staphylococcus aureus biofilms. J. Antibiot. 2012, 65, 453-459. [CrossRef]

29. Yan, Z.; Huang, M.; Melander, C.; Kjellerup, B.V. Dispersal and inhibition of biofilms associated with infections. J. App. Microbiol. 2020, 128, 1279-1288. [CrossRef]

30. Mosmann, T. Rapid colorimetric assay for cellular growth and survival: Application to proliferation and cytotoxicity assays. J. Immunol. Methods 1983, 65, 55-63. [CrossRef]

Publisher's Note: MDPI stays neutral with regard to jurisdictional claims in published maps and institutional affiliations.

(C) 2020 by the authors. Licensee MDPI, Basel, Switzerland. This article is an open access article distributed under the terms and conditions of the Creative Commons Attribution (CC BY) license (http://creativecommons.org/licenses/by/4.0/). 